\title{
Do Seasonal Changes and Climate Effect the Prevalence of Antibiotic Resistance of Acinetobacter calcoaceticus-baumannii Complex?
}

\author{
Meryem Güvenir ${ }^{1 *}$, Emrah Güler², Kaya Süer ${ }^{3}$ \\ ${ }^{1}$ Near East University, Vocational School of Health Services, Department of Medical \\ and Clinical Microbiology, Nicosia,Cyprus \\ ${ }^{2}$ Near East University, Faculty of Medicine, Department of Medical and Clinical Microbiology, Nicosia, Cyprus \\ ${ }^{3}$ Near East University, Faculty of Medicine, Department of Infectious Diseases and Clinical Microbiology, \\ Nicosia, Cyprus
}

Received: 21 May 2020

Accepted: 12 June 2020

\begin{abstract}
The high rate of carbapenem resistant Acinetobacter calcoaceticus-baumannii Complex (ABC) is indicated as a threat to public health. We aimed to determine the $\mathrm{ABC}$ isolated from Near East University hospital from 2016 to 2019 based on seasonality and climate changes. A total of 218 patients were examined between 2016 and 2019. All isolates were healthcare-acquired isolates, which are defined as those obtained after 48 hours of admission. All isolates were identified by a Phoenix 100 System. Antibiotic susceptibility analysis was reported based on EUCAST guidelines. Isolates were grouped according to seasons as follows: December through February as Quarter 1 (Q1); March through May as Quarter 2 (Q2); June through August as Quarter 3 (Q3); and September through November as Quarter 4 (Q4). Statistical analysis was performed with SPSS Ver 13.0 (SPSS Inc., Chicago, IL, ABD) program. There were significant differences between the number of patients with $\mathrm{ABC}$ infections according to years $(p=0.000)$. The rate of carbapenem resistance of $A B C$ was $86.2 \%(n=188)$. The resistance rates of the $\mathrm{ABC}$ isolates as well as carbapenem resistance peaked in October. The infection increased in the summer and decreased gradually in the autumn, winter and spring $(\mathrm{p}=0.009)$. No significant difference was found between the carbapenem resistance of $A B C$ infection and seasonality $(p=0.202)$. We have found that $\mathrm{ABC}$ infections and the carbapenem resistance of $\mathrm{ABC}$ increases in the summer months. However, more studies should focus on the epidemiological aspect of $\mathrm{ABC}$ infections.
\end{abstract}

Keywords: Acinetobacter baumanii complex, multi-drug resistance, sesaonality

*e-mail: meryemguvenir@hotmail.com 


\section{Introduction}

Acinetobacter baumannii-calcoaceticus complex $(\mathrm{ABC})$ is a major global health threat because of its ability to survive in different environments and also the increase level of antibiotic resistance [1,2]. The Centers of Disease Control and Prevention (CDC) and the World Health Organization (WHO) has categorized multidrug resistant (MDR) Acinetobacter as dangerous pathogens $[3,4]$. The details of the resistance patterns provide important insights into emerging pathogens besides being important for public health, infection control and antimicrobial stewardship approaches [5].

Seasonal and climate variations in the incidence of human infection can affect diagnosis and also give direction for infection prevention interventions $[6,7]$. Gram negative bacteria in particular are identified as exhibiting seasonal trends in human infection. However, a limited number of studies have reported the effects of seasonality on hospital associated infections $[8,9$, 10]. It has been reported that the prevalence of gram negative pathogens such as $\mathrm{ABC}$ might be increased during the warmer, summer months [11]. Additionally, some studies have indicated that the incidence peaks during winter but a lack of seasonality has also been indicated $[12,13]$. As Hippocrates stated in Book II of the Aphorisms, 'Every disease occurs at any season of the year, but some of them occur more frequently and have greater severity at certain times" $[14,15]$.

The objective of this study was to examine ABC isolated from Near East University hospital from 2016 to 2019 based on seasonality and climate changes.

\section{Material and Methods}

In this retrospective study, a total of 218 patients were received and examined between 2016 and 2019. When multiple isolates were detected in the same patient, only the first isolate obtained within a $>2$ days period was included in the study. All isolates were healthcare-acquired isolates, which are defined as those obtained after 48 hours of admission. Isolates were grouped according to specimen source (respiratory, skin, soft tissue, sputum, blood etc.). All isolates were identified by a Phoenix 100 System (Becton Dickinson, USA). Antibiotic susceptibility analysis was reported based on EUCAST guidelines. The antibiotics were grouped into classes: meropenem and imipenem (MEM/IPM) and gentamicin (GEN) as carbapenems;

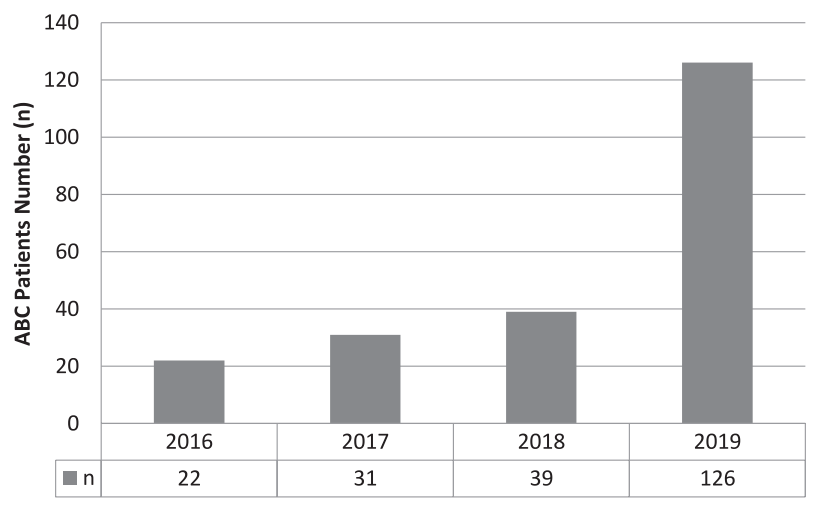

Fig. 1. Distrubition of the Abc infection according to years $(\mathrm{p}=$ $0.000)$.

ciprofloxacin as fluoroquinolones; piperacillintazobactam (TZP) as antipseudomonal penicillins and trimethoprim/sulfamethoxazole (TMP-SXT).

Isolates were grouped according to seasons into four quarters as follows: December through February as Quarter 1 (Q1); March through May as Quarter 2 (Q2); June through August as Quarter 3 (Q3); and September through November as Quarter 4 (Q4). One sample T-test was performed to evaluate the significance of ABC incidence between seasons (Q1,Q2 ,Q3,Q4). The Independent-sample $\mathrm{T}$ test was used to compare the average of age and gender, while the Pearson Chisquare test was used to find the difference between age and gender.

\section{Results and Discussion}

We retrospectively analysed $\mathrm{ABC}$ isolates from 218 patients at Near East University Hospital, located in Nicosia, North Cyprus from 2016-2019. From the two hundred and eighteen (218) patients, 82 $(37.6 \%)$ were female and $136(62.4 \%)$ were male, and their ages varied between 17-96 (with a median of 66.6 years). When we compared the average age of the male and female patients, a statistically significant difference was observed $(p=0.002)$. Accordingly, it is seen that older women patients are more likely to contract the $\mathrm{ABC}$ infection than men. In Table 1, the age groups and the sexes of $\mathrm{ABC}$ reproduced patients are compared, and it can be observed $\mathrm{ABC}$ infections in women over 65 years of age were found to be significantly higher $(\mathrm{p}=0.000)$.

Table 1. Evaluation of $\mathrm{ABC}$ patients in terms of age groups and gender.

\begin{tabular}{|c|c|c|c|c|}
\hline & $\leq 65$ age & $>65$ age & Total & $p$ \\
\cline { 1 - 3 } Male & $72(\% 52.9)$ & $64(\% 47.1)$ & $136(\% 100)$ & \multirow{2}{*}{0.000} \\
\cline { 1 - 3 } Female & $23(\% 28)$ & $59(\% 72)$ & $82(\% 100)$ & \\
\cline { 1 - 3 } Total & $95(\% 43.6)$ & $123(\% 56.4)$ & $218(\% 100)$ & \\
\hline
\end{tabular}




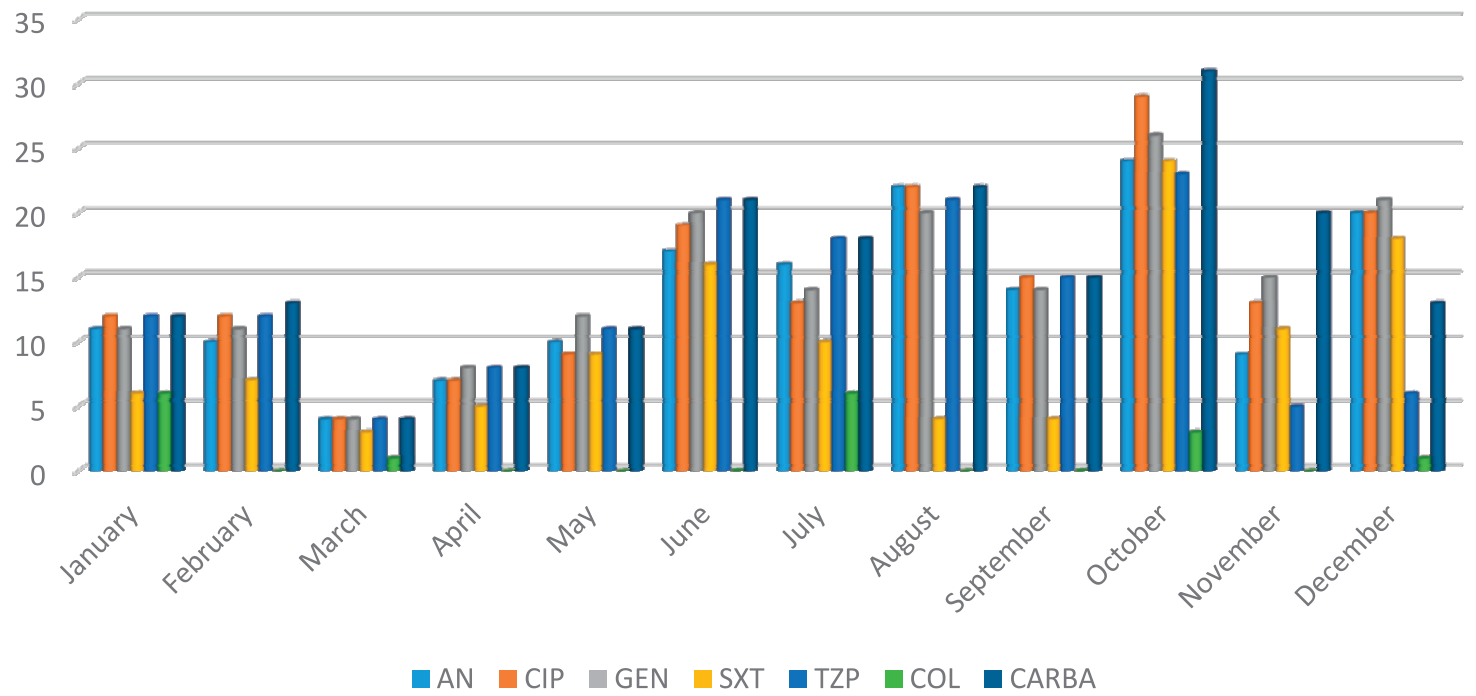

Fig. 2. The distrubition of the antibiotics of the Abc isolates according to months.

According to years, the $\mathrm{ABC}$ infection percentages were $10.1 \%$ in $2016,14.2 \%$ in $2017,17.9 \%$ in 2018 and $57.8 \%$ in 2019 (Fig. 1). There were significant differences between the number of patients with $\mathrm{ABC}$ infections according to years $(p=0.000)$. The sample types of the study yielded the following results: $41.3 \%$ $(\mathrm{n}=90)$ in suction fluid, $25.7 \%(\mathrm{n}=56)$ in sputum, $15.1 \%(\mathrm{n}=33)$ in urine, $10.1 \%(\mathrm{n}=22)$ in blood, $0.9 \%$ $(\mathrm{n}=2)$ in catheter tip and $6.9 \%(\mathrm{n}=15)$ in abscesswound.

Among the $\mathrm{ABC}$ strains, the amikacin resistance was $78.8 \%$, the ciprofloxacin resistance was $85 \%$, the gentamicin resistance was $81.9 \%$, the imipenem resistance was $85.1 \%$, the meropenem resistance was $86.6 \%$, the piperacillin-tazobactam resistance was $86.6 \%$ and the trimethoprim/sulfamethoxazole resistance was $61.3 \%$. The rate of carbapenem resistance of $\mathrm{ABC}$ was $86.2 \%(n=188)$. Fig. 2 shows the distribution of antibiotic resistance of $\mathrm{ABC}$ isolates according to the months. The resistance rates of the $\mathrm{ABC}$ isolates as well as carbapenem resistance peaked in October.

According to seasonality, the $\mathrm{ABC}$ infection percentages were $22.9 \%(\mathrm{n}=50)$ in $\mathrm{Q} 1,14.2 \%(\mathrm{n}=31)$ in $\mathrm{Q} 2,32.1 \%(\mathrm{n}=70)$ in $\mathrm{Q} 3$ and $30.7 \%(\mathrm{n}=67)$ in $\mathrm{Q} 4$ (Table 2). Accordingly, it was noted that the infection increased in the summer and decreased gradually in the autumn, winter and spring $(p=0.009)$. Fig. 3 shows the distribution of carbapenem resistance of $\mathrm{ABC}$ according to seasonality. The monthly incidence of carbapenem resistance of $\mathrm{ABC}$ isolates peaked in the summer (32.4\%). Also, no significant difference was found between the carbapenem resistance of $\mathrm{ABC}$ infection and seasonality $(\mathrm{p}=0.202)$.

Acinetobacter species is a multidrug resistant microorganism that can be found in hospitals worldwide that causes nosocomial infections [16-18]. Therefore, the clinical significance of $A$. baumannii is mostly due to its ability to easily acquire resistance to different groups of antimicrobials [19]. The Infectious Diseases Society of America has included A. baumannii in its list of six highly resistant pathogens that are frequently resistant to licensed antimicrobials [20]. $A$. baumannii is intrinsically resistant to many antimicrobial agents due to its selective ability to prevent various molecules from penetrating the bacterial outer membrane [21]. The combined resistance to fluoroquinolones, aminoglycosides and carbapenems was the most frequently reported resistance phenotype for Acinetobacter spp. in 2015 [22]. In this study, the resistance of the $\mathrm{ABC}$ strains to amikacin, ciprofloxacin, gentamisin, imipenem and meropenem were $78.8 \%$, $85 \%, 81.9 \%, 85.1 \%$ and $86.6 \%$, retrospectively. In our study, the rates of resistance to the indicated antibiotics were consistent with the literature [23-25].

Seasonal variation was first described in Acinetobacter spp in the 1970s [11]. However, two of the main studies on the seasonality of $\mathrm{ABC}$ (health care association infection) have been reported. Retaillau et al., who performed the first study in 1974-1977, indicated that health care association

Table 2. The distribution of the Abc infection according to seasonality.

\begin{tabular}{|c|c|c|c|c|c|c|c|c|c|c|c|c|}
\hline Season & \multicolumn{3}{|c|}{ Spring (S2) } & \multicolumn{3}{|c|}{ Summer (S3) } & \multicolumn{3}{|c|}{ Autmn (S4) } & \multicolumn{3}{|c|}{ Winter (S1) } \\
\hline Month & March & April & May & June & July & August & Semptember & October & November & December & January & February \\
\hline $\mathrm{Abc}(\mathrm{n})$ & 6 & 11 & 14 & 22 & 23 & 25 & 18 & 34 & 15 & 24 & 12 & 14 \\
\hline Total & \multicolumn{3}{|c|}{$31(\% 14.2)$} & \multicolumn{3}{|c|}{$70(\% 32.1)$} & \multicolumn{3}{|c|}{$67(\% 30.7)$} & \multicolumn{3}{|c|}{$50(\% 22.9)$} \\
\hline
\end{tabular}




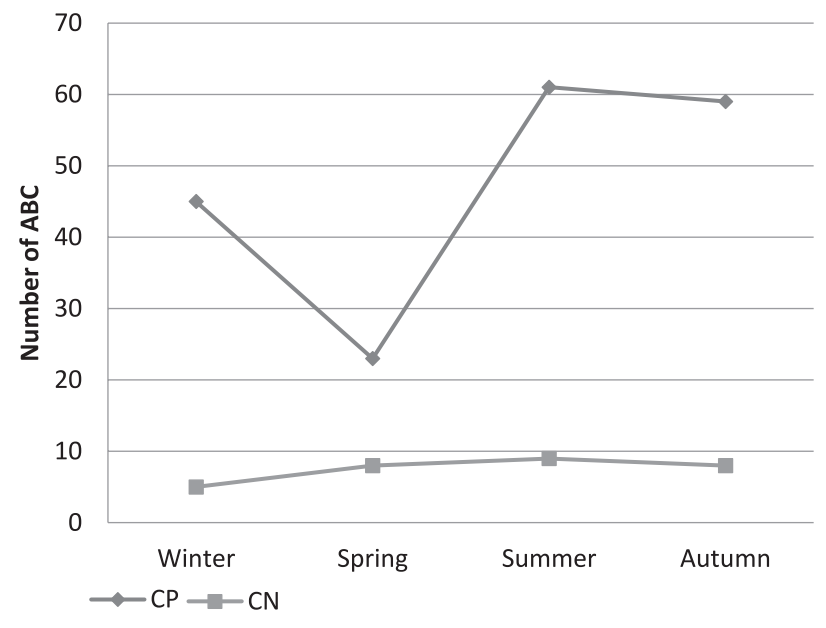

Fig. 3. Distrubition of the carbapenem resistance of the $A B C$ strains according to seasonality.

infection increased during the summer months [26]. Also, Gales et al. reported that the highest number of Acinetobacter spp infections occurred during the summer [27]. In our study, the highest number of ABC infections were also observed during the summer. There have been many suggestions regarding why $\mathrm{ABC}$ infections were highest in the summer [7, 9, 28, 29].

Two studies have focused on the seasonal variation and antimicrobial resistance of $\mathrm{ABC}$ isolates. One of them indicated that non-MDR ABC isolates were identified in warm months [13]. The other study reported that they found a greater association with temperature for imipenem-resistant isolates than imipenem susceptible isolates of $\mathrm{ABC}$ [30]. In our study, we found that the carbapenem resistance of $\mathrm{ABC}$ isolates peaked in summer, which is consistent with the findings of Fukuta et al. [13]. Also, we found that the rate of antimicrobial resistance was the highest in November according to the months.

\section{Conclusion}

In conclusion, we have found that $\mathrm{ABC}$ infections and the carbapenem resistance of $\mathrm{ABC}$ increases in the summer months. In summer season, when temperatures rises, sweating increases in healthcare staff parallelly. Hence, colonization of bacteria in the skin is facilitated and thus it may cause an increase of ABC-related infections. In addition, we think that the increasing use of air conditions and ventilators in the summer months is one of the factors causing the increase of ABC-related pneumonia especially in intensive care units. However, more studies should focus on the epidemiological aspect of $\mathrm{ABC}$ infections.

\section{Conflict of Interest}

The authors declare no conflict of interest.

\section{References}

1. KIM Y.A., KIM J.J., WON D.J., LEE K. Seasonal and Temperature-Associated Increase in Community-Onset Acinetobacter baumannii Complex Colonization or Infection. Ann Lab Med. 38, 266, 2018.

2. HOFFMAN-ROBERTS H., SCOBLE P., TABAK Y.P., MOHR J., JOHANNES R.S., GUPTA V. National prevalence of multidrug-resistant Acinetobacter baumanii infections in the ambulatory and acute care settings, including carbapenem-resistant Acinetobacter infections, in the United States in 2015. Open forum Infect Dis; 3 (Suppl 1), 1488, 2015.

3. Center of Disease Controll and Prevention. Antibiotic resisyance threats in the United States,2013 https:// www.cdc.gov/drugresistance/threat-report-2013/pdf/arthreats-2013-508.pdf. 2013.

4. World Health Organization. Global priority list of antibiotic-resistant bacteria to guide research, discover and development of new antibiotic. https://apps.who.int/ medicinedocs/documents/s23171en/s23171.en.pdf. 2017

5. GUPTA V., YE G., OLESKY M., LAWRENCE K., MURRAY J., YU K. Trends in resistant Enterobacteriaceae and Acinetobacter species in hospitalized patients in the United States: 2013-2017. BMC Infectious Diseases. 19, 74, 2019.

6. SIMONSEN L. The global impact of influenza on morbidity and mortality. Vaccine 17 Suppl 1, S3-10, 1999.

7. EBER M.R., SHARDELL M., SCHWEIZER M.L., LAXMINARAYAN R., PERENCEVICH E.N. Seasonal and temperature-associated increases in gram-negative bacterial bloodstream infections among hospitalized patients. PLoS One; 6:e25298, 2011.

8. ANDERSON D.J., RICHET H., CHEN L.F., SPELMAN D.W., HUNG Y.J., SEXTON D.J., RAOULT D. Seasonal variation in Klebsiella pneumonia bloodstream infection on 4 continents. J Infect Dis, 197, 752, 2018

9. PERENCEVICH E.N., MCGREGOR J.C., SHARDELL M., FURUNO J.P., HARRIS A.D., MORR,S J.G. JR, FISHMAN D.N., JOHNSON J.A. Summer peaks in the inciden. ce of Gram negative bacterial infection among hospitalized patinets. Infect Control Hosp Epidemiol; 29, 1124, 2008.

10. SMITH T.L., PULLEN G.T., CROUSE V., ROSENBERG J., JARVIS W.R. Bloodstream infections in pediatrics oncology outpatients: a new healthcare systems challenge. Infect Control Hosp Epidemiol. 23, 239, 2002.

11. RICHET H. Seasonality in Gram negative and healthcareassociated infections. Clin Microbiol Infect. 18, 934, 2012.

12. WISPLINGHOFF H., EDMOND M.B., PFALLER M.A., JONES R.N., WENZEL R.P., SEIFERT H. Nosocomial bloodstream infections caused by Acinetobacter species in United States hospitals: Clinical features, molecular epidemiology and antimicrobial susceptibility. Clin Infect Dis; 31, 690, 2000.

13. FUKUTA Y., CLARKE L.G., SHIELDS R.K. WAGENER N.M., PASCULLE A.W., DOI Y. Lack of seasonality in the occurrence of multidrug resistant Acinetobacter baumanii complex. Infect Control Host Epidemiol; 33, 1051, 2012.

14. FISHMAN D.N. Seasonality of infectious diseases. Annu Rev Public Health; 28, 127, 2007.

15. DOWELL S.F. Seasonal variation in host susceptibility and cycles of certain infectious diseases. Emerg Infect Dis; 7, 369, 2001. 
16. ANTUNES I.C.S., VISCA O., TOWNER K.J. Acinetobacter baumannii: evoluation of a global pathogen. Pathog Dis. 71, 292, 2014.

17. TSIOUTS C., KRITSOTAKIS E.L., KARAGEORGOS S.A., STARTAKOU S., PSAROLOGAKIS C., KOKKINI S., GIKAS A. Clinical epidemiology, treatment and prognostic factors of extencively drug-resistant Acinetobacter baumannii ventilator-associated pneumonia in critically ill patients. Int J Antimicrob Agents; 48, 492, 2016.

18. European Centre for Disease Prevention and Control Europen Antibiotic Awareness Day (EAAD) summary of the latest data on antibiotic resistance in the European Union. EARS-Net Surveillance data 2015. Stocjholm: ECDC; 2016.

19. HOUANG E.T., SORMUNEN R.T., LAI L., CHAN C.Y., LEONG A.S. Effect of desiccation on the ultrastructral appearances of Acinetobacter baumannii and Acinetobacter Iwoffii. J Clin Pathol; 51 (10), 786, 1998.

20. TALBORT G.H., BRADLEY J., EDWARDS J.E. JR, GILBERT D., SCHELD M., BARTLETT J.G. Bad bugs need drugs: an update on the development pipeline from the Antimicrobial Availability Task Force of the Infectious Diseases Society of America. Clin Infect Dis; 42 (5), 657, 2018.

21. MUNOZ-PRICE L.S., WEINSTEIN K.A. Acinetobacter infection. N Eng J Med; 358 (12), 1271, 2008.

22. European Centre for Disease Prevention and Control. Carbapenem-resistant Acinetobacter baumannii in healthcare settings -8 December 2016. Stockholm: ECDC; 2016.

23. SAY COSKUN, CALISKAN E., CICEK A.C., TURUMTAY H., SANDALLI C. B-lactamase genes in carbapenem resistance Acinetobacter baumanii isolates from a Turkish University hospital. J Infect Dev Ctries; 13 (1), 50, 2019.

24. ISLER B., DOI Y., BONOMO R.A., PATERSON D.L. New treatment options against Carbapenem -resistant Acinettobacter baumannii Infections. Antimicrob Agents Chemother; 63, e01110-18, 2019.
25. ALCÁNTAR-CURİEL M.D., ROSALES-REYES R., JARILLLO-QUİJADA M.D., GAYOSSO-VÁZQUEZ C., FERNÁNDEZ-VÁZQUEZ J.L., TOLEDANO-TABLEROS J.E., GIONO-CEREZO S., GARZA-VILLLAFUERTE P., LÓPEZ-HUERTA A., VENCES-VENCES D., MORFÍN-OTERO R., RODRÍGUEZ-NORIEGA E., LÓPEZ-ÁLVAREZ M.D.R., ESPINOSA-SOTERO M.D.C. ANDSANTOS-PRECIADO J.I. Carbapenem-Resistant Acinetobacterbaumannii in Three Tertiary CareHospitals in Mexico: VirulenceProfiles, Innate Immune Responseand Clonal Dissemination.Front. Microbiol. 10:2116.doi: 10.3389/fmicb.2019.02116, 2019.

26. RETAILLIAU H.F., HIGHTOWER A.W., DIXON R.E., ALLEN J.R. Acinetobacter calcoaceticus: a nosocomial pathogen with an unusual seasonal pattern. J Infect Dis; 139, 371, 1979.

27. GALES A.C., JONES R.N., FERWARD K.R., LINARES J., SADEC H.S., VERHOEF J. Emerging importance of multidrug resistant Acinetobacter species and Stenotrophomonas maltophilia as pathogens in seriously ill patients: geographic patterns, epidemiological features, and trends in the SEN-TRY Antimicrobial Surveillance Program (1997-1999). Clin Infect Dis; 32 (suppl 21), 104, 2001.

28. MCDONALD L.C., BANERJEE S.N., JARVIS W.R. Seasonal variation of Acinetobacter infections: 1987-1996. Nosocomial Infections Surveillance System. Clin Infect Dis; 29, 1133, 1999.

29. SCWAB F., GASTMEIER P., MEYER E. The warmer the weather, the more gram-negative bacteria-impact of temperature on clinical isolates in intensive care units. PLos One; 9, e91105, 2014.

30. DE SILVA P.M., CHONG P., FERNANDO D.M , WESTMACOTT G., KUMAR A. A Effect of Incubation Temperature on Antibiotic Resistance and Virulence Factors of Acinetobacter baumannii ATCC 17978. Antimicrob Agents Chemother; 62, 2018. 
